\title{
How Employee Competency and Self Efficacy Affect Employee Work Engagement in Human Resource Development Agency (BPSDM) Ministry of Law and Human Rights Republic of Indonesia
}

\author{
Ari Anggarani Winadi Prasetyoning Tyas \\ Universitas Esa Unggul \\ Email: ari.anggarani@esaunggul.ac.id \\ Syarifudin Tippe \\ Universitas Negeri Jakarta \\ Email: stippe035@gmail.com \\ Slamet Sutanto \\ Universitas Negeri Jakarta \\ Email: sutanto45@yahoo.com
}

\begin{abstract}
The radicalism that leads to terrorism is a threat to almost every country in the world, leading many countries to employ a deradicalization program to deradicalize people that have been influenced by terrorist ideology. This research purpose is to evaluate the effectiveness of deradicalization effort conducted through "terrorism client guidance program at Surakarta Correctional Facility". Using the CIPP model of evaluation, data is collected from eighteen terrorism clients and a few structural officials as well as all related documents at Surakarta Correctional Facility. The result of this study found that: (1) Evaluation of context component is worth average, (2) Evaluation of input component is worth poor, (3) Evaluation of process component is worth good, and (4) Evaluation of product component is worth average. Overall, the effectiveness of deradicalization conducted through guidance for terrorism client program at Surakarta Correctional Facility is worth average. Although the total evaluation merit of the terrorist client's guidance program is still in the level of average, however, the author suggests that the program should be continued by revising some areas of concern.
\end{abstract}

Keywords: Deradicalization, Evaluation Program, Guidance of Terrorism Client.

Received: 1 October 2020 ;

Accepted: 11 November 2020 ;

Publish; December 2020.

\section{How to Cite:}

Prasetyoning Tyas, A.A.W., Tippe, S., Sutanto, S. (2020). How Employee Competency and Self Efficacy Affect Employee Work Engagement in Human Resource Development Agency (BPSDM) Ministry of Law and Human Rights Republic of Indonesia. International Journal of Human Capital Management, 4 (2), 125-140. https://doi.org/10.21009/IJHCM.04.02.11

\section{INTRODUCTION}

Quality of human resource in law is required to have maturity of mind, culture, ethic and conscience in implementing and performing fundamental value of law. Each employee possesses a distinct level of employee engagement in a workplace. Employee engagement means a concept of person relating to how an employee dedicates to his workplace, fidelity, responsibility, and performance inside and outside working hours. According to (Budiastuti, 2018)(Truss et al., 2013), dissimilarity between 'doing' and 'being' engagement shows that employee engagement is a theme demanded to be implemented, perceived equally, and developed as a concept. Abraham Maslow 
states that each person is supposed to meet basic needs such as security and shelter before desiring to grow. At the end, employee engagement plays an important role in identifying someone's engagement level and motivation at work. By having this information, management is believed to be able to create a working condition which supports employees to develop their ability and achieve vision, mission, and goal in a workplace (Wirotama, 2017). Although employee engagement is invisible, it is crucial for employer to take it into account as it might restrain an organization from achieving its goal. Moreover, employee engagement could be worse if both employer and co-workers are ignorant each other. Employee engagement in Human Resources Development Agency (BPSDM) of Ministry of Law and Human Rights Republic of Indonesia is obviously as same as Indonesian condition thoroughly. Ministry of Law and Human Rights Republic of Indonesia has an organizational behaviour; that is KAMI PASTI (we are sure) which stands for Professional, Accountable, Synergic, Transparent, and Innovative. These behaviours become a fundamental procedure for all units in Ministry of Law and Human Rights Republic of Indonesia including Human Resources Development Agency (BPSDM) (Marjoeki, 2016). Employee engagement has been appealing for academics and developed by human resource practitioners (Albrect, 2010) though it is newly discovered (Macey, 2009). It is defined as employee's positive feeling and point of view, and characterized as remarkable resilience, vigour, enthusiasm, dedication, and absorption (Suwandana, 2016)

One thing which affects employee engagement is employees' perception of work and other aspects relating to their work. The perception shows employees' confidence in completing their task. Employees' self-efficacy toward their power or ability is to reach a success so that they are able to work harder, be more enthusiastic, and perform their best. Self-efficacy and work engagement are goals for those who are responsible for increasing a leadership quality. Selfefficacy and engagement contribute positively as these affect employees' performance through some processes such as choices, efforts, performances, initiatives, and other roles (Federici \& Skaalvik, 2011). Self-efficacy in socio-cognitive theory is seen as belief and situation of someone's ability, then this concept is expanded in research of personality and organization focusing on general self-efficacy. General self-efficacy reflects a tendency to recognise oneself as a person having ability to affect environment successfully and to reach goal in all aspects and situations. People with low general self-efficacy tend to be more stressed and fatigue than those who have high general self-efficacy since low general self-efficacy people are more likely to define an ambiguous situation as an anxiety, besides elucidate a failure at work and academic as a threat rather than a challenge. In an organizational literature, general self-efficacy represents disposition of 'core self-evaluation' connected to various indicators of work welfare and job performance (Lauermann, 2016). Self-efficacy is a belief occurring due to self-confidence in carrying out a task to attain a success. Confidence correlates with employees' motivation to feel more optimistic on ability. Self-efficacy is significantly important for employees, by increasing their own ability, to fulfil their task so that a company could run optimally. Therefore, self-efficacy is needed to pursue employees work well and perform best performance.

Ardi et al., (2017) affirm that self-efficacy can be seen from three scopes. First is selfefficacy level of each person in finishing task. This varies in terms of task difficulty. Individual has high self-efficacy both on simple and complicated task, but individuals with high self-efficacy tend to take more complex task in accordance with their ability. The second relates to individual's mastery in certain field (generality). Individuals are able to declare themselves to have selfefficacy on either many activities or merely on certain domains. People with high self-efficacy could master many fields at once to finish a task while those with low self-efficacy are only proficient in some field to complete a task. Third is strength. This scope emphasizes strength level and stability toward belief. Self-efficacy indicates that an action results in what is expected since self-efficacy is a basis in making a hard effort, in solving a problem indeed. Form the aforementioned explanation, it can be said that self-efficacy covers three areas: level, generality, and strength.

Being a public servant is certainly not a short time for civil servants as they should lead themselves to attend programme and join training to improve. Civil servants should have a good mindset in facing a strong competition. Those who are able to cope with a strong competition are those with these competencies: 1) technical competency measured from the level and specialization of education, functional technical training and technical work experience; 2) managerial competency measured from level of education, structural or management training and leadership experience; 3) socio-cultural competency measured from work experience relating to pluralism of society in terms of religion, ethnicity, culture and nationalism perspective (Marjoeki, 2016). Competency is identified through minimal work as a result of ability while ability is an 
outcome of applying knowledge, skills and behaviour thoroughly to create a competency. Therefore, before achieving a competency which is indicated by a good performance, an employee should improve knowledge, skill and attitudes. This improvement can be obtained through education or training. To develop a competent employee, employer should involve employees in making a decision in which it provides a sustainable learning environment of required skills. When employees have a clear idea regarding expectation and strategic goals of an organization, task and work will be arranged based on expected goals. This provides job satisfaction to employees and increases their commitment to both individual and team work entirely. Loyal competent employees could increase company potential success as they improve work efficiency and reduce waste (Osei \& Ackah, 2015) Despite such number of studies, there has been scant research done in government. Most of those studies have been carried out in large organization such as hospital, university and other big companies. There was also insufficient study about the effect of employee competency on employee engagement mediated by self efficacy. Hence, this research fills the gaps of previous studies and worth investigating

\section{LITERATURE REVIEW}

\section{Employe Engagement}

Employee engagement is often associated with the performance of a result of an organization; the higher the employees involve, the more improved the employees' performance are. Employee engagement is in line with employee who has a high moral value. Besides a vigour, dedication to an organization and to every process running in an organization could lead employee possess absorption and effectivity in every work they face (Andrianto \& Alsada, 2019). Asserts that employee engagement is a positive attitude of employee and organization (commitment, involvement, and engagement) to cultural values and achievement of an organization (Budiastuti, 2018).

Schaufeli and Bakker in Bakker and Leiter define employee engagement as a positive and satisfying mind related to work shown through a vigour, dedication, and absorption. In an engagement, fulfilment contrasts with an emptiness of life as exhaust. Vigour is characterised by a high level of energy and mental endurance at work. Dedication refers to someone's strong engagement, significant, and enthusiasm at work. Absorption is shown through a focus and enjoyment at work (Bakker \& Leiter, 2010). From various theoretical studies and relevant previous research from several experts who support this research, it can be synthesized that employee engagement, an employee who has a positive attitude to work, is committed to work, is enthusiastic, initiative and proud of his work, and is responsible for his work. working with several indicators, namely: 1) Work enthusiasm (Vigor), 2) Dedication, 3) Concentration (Absorption).

\section{Self Efficacy}

Self-efficacy is a key element of social cognitive theory. Bandura defines self-efficacy as people's assessment on their own ability to arrange and run actions needed to achieve certain performance. A belief of self-efficacy affects the way people react and is a conceptual element in recognizing others in different context. Self-efficacy is one's belief of what to achieve in certain context, not an assessment of his own ability (Federici \& Skaalvik, 2011).

Bandura divides self-efficacy indicators into three: level, generality, and strength. 1) Magnitude or level indicator: it refers to level of difficulty of the task that a person is able to handle. Self-efficacy level of each person is different one from others while level of task difficulty, either complex or not, determines one's self-efficacy. In one task, if there is no significant obstacle to deal with, then the task will be easy, and every person must have a high self-efficacy on this. For example, Bandura explains the belief of ability to jump that an athlete has. An athlete believes that he is able to jump over a barrier wood on different heights which means everyone could improve and enhance his self-efficacy by facing more challenging and complex task. 2) Generality indicator. It means a various situation in which a self-efficacy can be applied.

One could assess his own self-efficacy either on many tasks or merely certain. The more someone applies his self-efficacy on different situations, the higher his self-efficacy level is. Situations in general vary in terms of its dimensions including the similarity level of activity, feeling in which ability (behaviour, cognitive, affective), qualitative characteristics of situation, and individual characteristic refer to. 3) Strength indicator. It correlates with someone's selfefficacy when facing a task or problem. A weak self-efficacy could be easily omitted with anxious 
experience when handling a task, otherwise, it could be a strong persistent despite of infinite challenges. This dimension includes level of one's stability toward his own belief. Hence, this stability determines one's perseverance and persistency. From the explanation, it can be concluded that self-efficacy dimensions cover: task difficulty level faced by individuals and their belief in solving it, various activity so that an assessment of self-efficacy can be applied, and one's strength of self-efficacy in dealing with problem (Bandura, 2009).

Self-efficacy is situational and contextual, depends on how the situation is and in what context. Dimensions of self-efficacy covers: 1) level, how far a person could determine difficulty level in fulfilling a task. Assessment of this aspect can be seen from several things; whether an individual could create a challenging target and achieve it though it is hard, and whether an individual could recognise his interest and ability to choose an appropriate job. 2) strength, how strong and confident a person could be seen from his consistency in accomplishing task. This aspect can be measured through increasing effort in failure, belief in finishing task, calmness in facing a hard task, and his commitment in achieving a target. 3) generality, how one could generalise task and previous experience in handling a work, for example, he could make an experience as challenge or failure. This aspect is supposed as a good thing if someone believe that his previous experience helps his current job, responds various situation well, and as a path to success (Ardi et al., 2017). Based on the results of the study of some of these concepts, it can be synthesized that Self Efficacy is a belief that arises because of having confidence in one's abilities in carrying out a job, so that it is able to obtain success. When faced with obstacles, setbacks and failures, those who doubt their abilities slacken their efforts, give up prematurely, or accept worse solutions. Those who have strong faith in their abilities redouble their efforts to master the challenge. These abilities and beliefs include (1) ability levels (magnetitude / level); (2) strength ability (streght); and (3) generality.

\section{Employee Competency}

Competency is a basic characteristic for individual to contribute to job performance or role and success of organization. Specific competency for certain work is a familiar requirement set through work requirement, work analysis. Competency requirement could go beyond specific job for some job, general job, or a whole organization. This competency is more general, for instance technical expertise or adaptability (Heneman, Judge, 2015). Competency is indicated by a good work minimally as ability result. Ability is a result of applying knowledge, skill, behaviour and basis for achieving competence. Therefore, before achieving a competence indicated by a good work, someone should make an improvement of knowledge, skill, and behaviour. One of the improvements can be made by taking education, joining training and others. This means basically everyone has a competence. Then, through an appropriate effort and means, ability can be developed through education and training or experience in order to create an effective competence to achieve organization goals. Ability can be a form of knowledge, general knowledge regarding work and position. Skill is mastery a knowledge of general and specific skill. Attitude means one's mental condition towards an object relating to his job. Competence covers: 1) technical competence; knowledge and skill: to accomplish agreed outcome, ability to think about problem and a new alternative. 2) conceptual competence; ability to frame a big picture in examining expectations and changing perspective. 3) competence to live dependently, to interact effectively to others including ability to hear, communicate, and get a new alternative, see a whole organization effectively (Sedarmayanti, 2017).

Three main components in competence formation are knowledge, ability, and attitude. Knowledge is an employee's information to do his job and responsibility in taking his job. Employee's knowledge also determines whether an assigned job will be successful; employee who has a sufficient knowledge will improve a company's efficiency. (Adianita et al., 2017). So based on the results of the study of a number of concepts above, it can be synthesized that competence is the skills, knowledge, attitudes and abilities of employees. Competence is the basic foundation of people's characteristics and indicates how to behave or think, equate situations, and support over a long period of time. There are three individual competency components, namely; (1) Intellectual competency, (2) Emotional competency, (3) social competency.

\section{Hypothesis Development}

Competency is a description of the behavior while competency (skills) as a description of a job or job results. Competency refers to the characteristics that underlie behavior that describes motives, personal characteristics (characteristics), self-concept, values, knowledge or skills 
brought by a superior performer, thus competency consists of several different types of characteristics encouraging behavior. The foundations for these characteristics are evident in the way a person behaves at work. Competency is about what kind of people they are and what they can do. Not what they might do. (Mangkuprawira, 2009)

Employees who are committed and feel attached to their jobs are those who are emotionally connected to the organization and their co-workers. This opinion is based on the Employee Engagement Model of Entec Corporations (Koscek, 2007). That the research results show agent competency has a significant positive effect on agent job involvement. In other words, the higher the agent's competency, the higher the work involvement with partner banks .It is also strengthened by (Unnikrishnan, 2017). This means that the success of an organization owes primarily to the competency of their managers. The core idea of this study is to conduct empirical investigations on the various factors of managerial competency, their roles and effectiveness on employee engagement.

From the theoretical study, previous research and the theoretical framework above, it can be said that Employee Competence has an influence on Employee Engagement in a company. $\mathrm{H}_{1}$ : There is a positive effect of Employee competency on Employee Work Engagement

Self-efficacy is a belief that arises because you have confidence in your ability to carry out a job, so you can get success. Confidence relates to the motivation or motivation that employees have to be more confident and have confidence in their own abilities. Self-efficacy is needed in employees, by increasing the ability to do the tasks given so that the company runs optimally and employee performance will increase. Because of this, self-efficacy is needed to make employees able to work well and have high performance. Belief in self-efficacy, belief in success that is always achieved makes a person work harder and always produce the best. Thus it can be said that self-efficacy can improve individual performance (Trilolita \& Ardi, 2017)

According to hewit in Azoury et al., (2013) employee engagement is a positive attitude of employees and organizations (commitment, involvement and attachment) to cultural values and the achievement of company success. Work engagement is a positive state of mind for employees related to job fulfillment, which has characteristics, vigor, dedication, and absorption. (Schaufeli \& Bakker, 2013). Apart from that, other research findings indicate that leader behavior, self-efficacy, and job satisfaction have a direct effect on job performance of the Ministry of Education, Youth and Sports in Palembang City (Fattah, 2017) This concept is strengthened by the research of Trilolita et al., (2017). The results showed that there was a significant effect of self-efficacy on employee performance, significant from employee engagement to employee performance.

However, research conducted by Federici \& Skaalvik (2011) states that three different NPSES models were tested. Both first and second order CFA confirm that primary self-efficacy represents eight dimensions. In addition, both structural models have an acceptable fit to the data and reveal that primary self-efficacy is positively related to job engagement. Wen \& Driscoll (2017) also confirm that the SEM findings support the hypothetical model. Self-efficacy can lead to a balance of work and engagement despite role demands.

This study reveals a full-fledged mediation model in which transformational leadership explains extra role performance through self-efficacy and job engagement. (Salanova et al., 2011) This study shows the results that self-efficacy has a positive and significant effect on job involvement. (Suwandana, 2016). There is a significant effect of Self Efficacy on employee engagement according to research (Ardi et al., 2017) From the theoretical studies, previous research and the theoretical framework above, it can be said that Self Efficacy has an influence on Employee Engagement in a company.

$\mathrm{H}_{2}$ : There is a positive effect of Self Efficacy on Employee Engagement

According to Mc.Clelland in Sedarmayanti from the book Human Resource Management, he says that Competency is a fundamental characteristic that a person has that directly affects, or can predict, excellent performance. In other words, competence is what our standing performers do more often, in more situations, with better results, than what policy assessors do (Sedarmayanti, 2007). Self-efficacy provides the foundation for human motivation, and personal achievement. People tend to be satisfied with their jobs when they feel competent to do their job duties or achieve their work goals (Luthan, 2011). Efficacious individuals have stronger confidence in their ability to successfully perform task situations, set more challenging goals for themselves, invest more, last longer and are better at coping with failed experiences than people low in self-efficacy. (Heuven et al., 2006 ). Researchers found that people with high levels of self-efficacy were more 
able to solve difficult situations than individuals who were efficacious.(Yakın \& Erdil, 2012). The results showed that GPK competence positive relationship with teaching efficacy,the predictive effects identified were thus specific to teacher professional competency. Possible implications for burnout prevention are discussed (Lauermann, 2016)

Supported also by the results of research which states that traditional lectures and simulation-based communication training can result in increased communication competency and self-efficacy among nurses. Therefore, the introduction of simulation-based training for in-service nursing education can improve the communication performance of nurses in clinical practice(Shu, 2014), From theoretical studies, previous research and the theoretical framework above, it can be said that Employee Competency has an influence on Self Efficacy in a company.

$\mathrm{H}_{3}$ : There is a positive effect of Employee Competency on Self Efficacy

Perspective is important for looking at organizational behavior. Providing unique and important opportunities to increase personal and organizational effectiveness. (Griffin, 2012) Knowledge, skills, or attitudes that enable a person to effectively carry out work activities or functions given to the standards expected in the job (Nikolov et al., 2014). Self-efficacy beliefs are beliefs about competency - what we know about the world and what we know how to do in the world. Competency includes "the quality and range of cognitive constructs and behaviors that individuals are capable of" and the ability to "construct (produce) a variety of behaviors under appropriate conditions". Self-efficacy beliefs are assessments of our ability to use our competency in specific domains and situations. Moreover, self-efficacy beliefs are not a contextual assessment of competency of competences divorced from situations; rather, beliefs about what we can do with our skills and abilities in certain contexts and conditions (Maddux \& Volkmann, 2010)

Kahn defines employee work engagement as "the use of organizational members to their job roles; in engagement, people employ and express themselves physically, cognitively, and emotionally during the role performance ". Central to this definition is the idea that engaged employees "give their all" in the workplace. (Kinicki \& Fugata, 2016). Supported by the results of research which states that employee competency affects organizational commitment through selfefficacy (Darmawa et al., 2019). The results showed that teacher competency indirectly through self-efficacy had an effect on teaching efficacy (Lauermann, 2016). Subsequent research also states that communication competency through self-efficacy affects communication training. (Shu, 2014). From the theoretical study, previous research and the theoretical framework above, it can be said that Employee Competency has an influence on employee work engagement through Self Efficacy in a company.

$\mathrm{H}_{4}$ : There is a positive indirect effect of Employee Competency on Employee Work Engagement mediated by Self Efficacy

\section{RESEARCH METHOD}

In accordance with the objectives of the research, this study examines the causal relationship between the variables of employee competency, self efficacy and employee work engagement. Quantitative data were collected from 221 respondents who work at Human Resoruce Development Agency (BPSDM) Ministry of Law and Human Rights Republic of Indonesia. To examine the relationship between variables and measure the effect of one variable on other variables is processed by using SPSS and Structural Equation Modeling (SEM) using LISREL. The relationship between these variables is a direct and indirect effect of exogenous variables on endogenous variables. In this study the exogenous variable is Employee Competency, the dependent endogenous variable is Employee Work Engagement, and the endogenous mediating variable is Self Efficacy.

Data about the Employee Work Engagement, Employee Competency, and Self Efficacy were collected using measurement instruments developed from the theoretical studies. Employee Work Engagement is measured using 3 indicators consisting of Vigor (VIG), Dedication (DED), and Absorption (ABS). The Employee Competency is measured using 3 indicators namely Intellectual (INT), Emotional (EMO), and Social (SOS). Self Efficacy is measured using 3 indicators namely Leverage (LEV), Generality (GEN) and Strength (STR). Primary data were quantified using a Likert scale consisting of five rating in accordance with the contents of the statements. The pilot study was carried out by taking 30 respondents who were parts of the population and outside the determined number of samples. Validity test is done by testing the loading factor on each indicator against the variable. The indicator is declared valid if the loading factor reaches an agreement of LF $>0.5$ and value of the critical $t_{\text {count }}>1.97$, and reliable when 
the value of $C R>0.7$ and VE $>0.5$ (Hair et al., 2014). Population in this study were all employees in BPSDM HAM RI for Group III (three). The total number of group III employees by 2008 was 221. Sample in this research applied non-probability sampling through saturated sampling based on criteria stated by ( $\mathrm{Jr}$ et al., 2014) that saturated sampling was sampling technique when all members of population were employed. In other words, it was census.

\section{RESULT AND DISCUSSION}

Based on the data collection, the research respondents were categorized into gender, age, educational background, and length of employment. The results of respondents' profile analysis are summarized in the following table:

Table 1 : Responden Profile

\begin{tabular}{cccc}
\hline $\begin{array}{c}\text { Respondent } \\
\text { Identities }\end{array}$ & Category & Total & Percentage \\
\hline Gender & Male & 123 & $56 \%$ \\
female & 98 & $44 \%$ \\
\hline Age & $21-26$ years old & 5 & $2 \%$ \\
& $27-32$ years old & 42 & $19 \%$ \\
& $33-38$ years old & 62 & $28 \%$ \\
& $>$ 38 years old & 112 & $51 \%$ \\
\hline Group & Group A & 53 & $23 \%$ \\
Background & Group B & 59 & $28 \%$ \\
& Group C & 55 & $25 \%$ \\
& Group D & 54 & $24 \%$ \\
\hline Length of & $1-3$ years & 24 & $11 \%$ \\
Employment & 4- 6 years & 22 & $10 \%$ \\
& $7-9$ years & 34 & $15 \%$ \\
& $>9$ years & 141 & $64 \%$ \\
\hline
\end{tabular}

The data in the table above indicate that the majority of the respondents is male, aged $>$ 38 years, Background Group B with length of employment $>9$ years.

Based on confirmatory factor analysis (CFA), it can be declared that all indicators are valid with the loading factors range from 0.50 to $0.92>0.5$, and a $t_{\text {count }}>1.97$. The result of construct reliability (CR), variance extracted (VE) and Cronbach alpha (CA) tests shown in table 2 indicated that all items are valid and reliable.

Table 2 : The Results of Validity and Reliability Test

\begin{tabular}{ccccc}
\hline \hline Variable & Valid Indicator & CR & AVE & CA \\
\hline WEE & 13 & 0.93 & 0.51 & 0.97 \\
\hline EC & 16 & 0.95 & 0.50 & 0,95 \\
\hline SE & 16 & 0.94 & 0.50 & 0.96 \\
\hline \hline
\end{tabular}

The value of $\mathrm{CR}>0.7, \mathrm{VE}>0.5$ and $\mathrm{CA}>0.7$ indicate that all instruments are reliable (Hair et al., 2014). It can be concluded that all instruments are appropriate to use for the next analysis. A full model analysis is performed after it is ensured that all indicators on each variable have been declared valid and reliable. Analysis of the results of data processing at the full model of Structural Equation Modelling (SEM) is carried out with the Goodness of Fit and statistical tests. Table 3 below summarizes the results of the test.

Table 3 : Fitness Indices of the Model and Their Level of Accetance

\begin{tabular}{lllll}
\hline \hline Criteria & Fit Index & Recommended Value & Result & Conclusion \\
\hline Absolute & Chi-Square, & 1085.63 & 102.46 & Goog Fit \\
Fit Indices & $(d f=834)$ & & & \\
& RMSEA & $0.05<R M S E A \leq 0.08$ & 0.12 & Good Fit \\
& $G F I$ & $G F I \geq .90$ & 0.91 & Good Fit \\
\hline Incremental & AGFI & $A G F I \geq 0.90$ & 0.82 & Good Fit \\
Fit Indices & NFI & $N F I \geq 0.90$ & 0.95 & Good Fit
\end{tabular}




\begin{tabular}{lllll} 
& $C F I$ & $C F I \geq 0.90$ & 0.96 & Good Fit \\
& RFI & RFI $\geq 0.90$ & 0.92 & Good Fit \\
\hline $\begin{array}{l}\text { Parsimony } \\
\text { Fit Indices }\end{array}$ & AIC & $\begin{array}{l}\text { AIC }<\text { saturated }=90.00<\text { Independence } \\
=2380.55\end{array}$ & 144.46 & Good Fit \\
& CAIC & $\begin{array}{l}\text { CAIC }<\text { saturated }=287.92< \\
\text { Independence }=2420.14 \\
\text { E }<\text { saturated }=0.41<\text { Independence }= \\
\\
\text { ECVI }\end{array}$ & 0.82 & Good Fit \\
& & Good Fit \\
\hline \hline
\end{tabular}

Researchers are not required to fulfill all the criteria of goodness of fit. The use of 4-5 criteria is sufficient to assess the goodness of fit of a model as long as it represents the criteria of absolute fit indices, incremental fit indices, and parsimony fit indices (Hair et al., 2014). Hence, it can be declared that the model reached a good fit.

The results of the structural model analysis produce two structural equations which show the influence between variables. The structural equation of the model being tested are as follows: $\mathrm{SE}=0.62 * \mathrm{EC}$, Errorvar. $=0.62, \mathrm{R}^{2}=0.38$
(0.069)
$(0.084)$
9.00
7.34
$\mathrm{WEE}=0.49 * \mathrm{SE}+0.15 * \mathrm{EC}$, Errorvar. $=0.65, \mathrm{R}^{2}=0.35$
$(0.086) \quad(0.073) \quad(0.091)$
$\begin{array}{lll}5.73 & 2.07 & 7.05\end{array}$

From the equation of structure (1) it is obtained that the value of $\mathrm{R}^{2}=0.38$ which means that the formation of SE by EC is $38 \%$, while the remaining $62 \%$ is determined by other variables outside the test in this study. The second structural equation it is known that $\mathrm{R}^{2}=0.35$ which means that WEE can be explained by SE and EC by $35 \%$. In other words, the formation of WEE by SE and $\mathrm{EC}$ is $35 \%$, while the remaining $65 \%$ is formed by other variables not tested in this study. The full structural model is shown in figure 1 and 2 below:

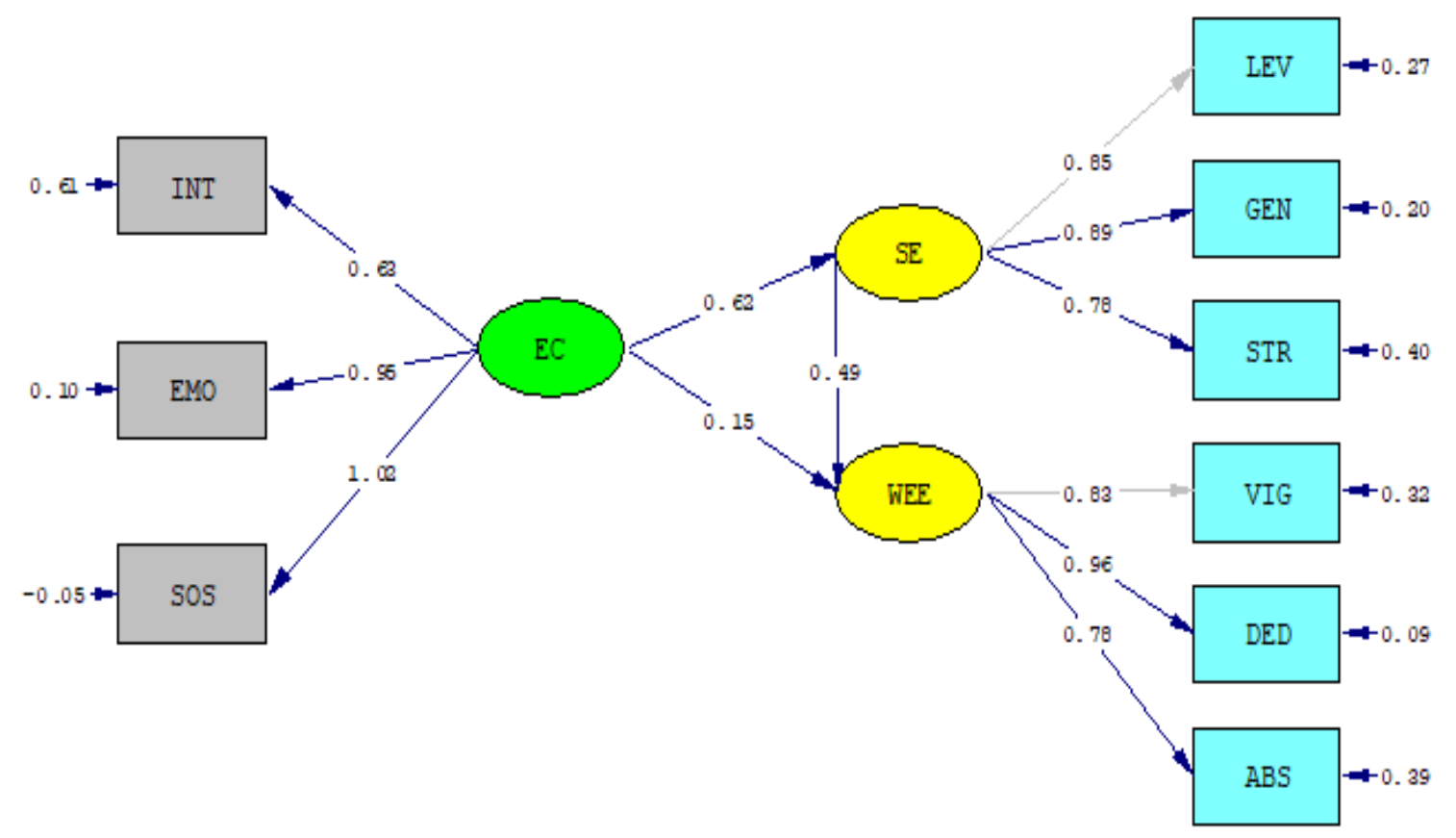

Chi-8quare $=102.46, \mathrm{df}=24, \mathrm{p}-\mathrm{value}=0.00000, \mathrm{RMSEA}=0.122$

Figure 1. Structural Model of Latent Variable Path Source : Lisrel Output 


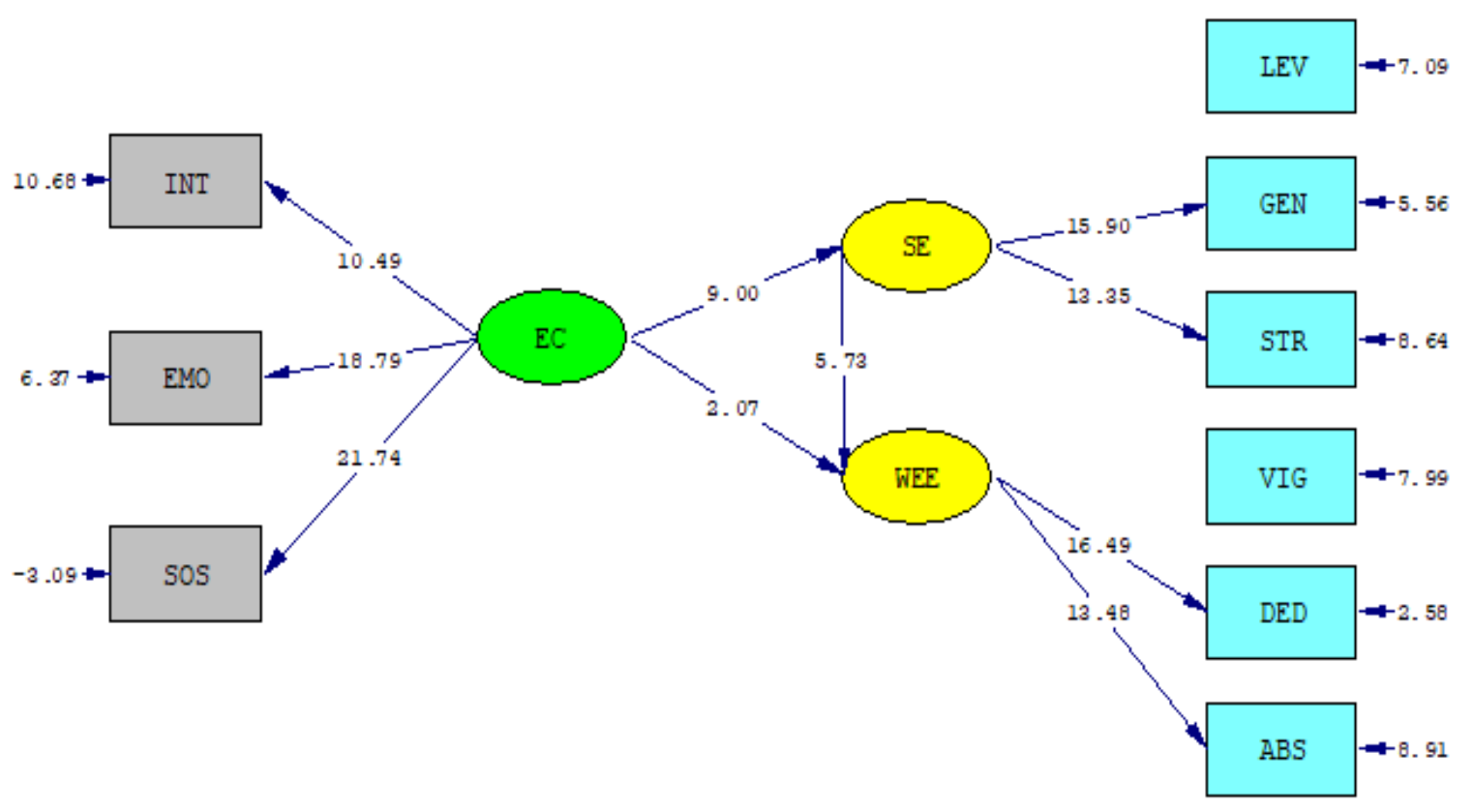

Chi-3quare $=102.46$, df $=24$, p-value $=0.00000$, RMSEA $=0.122$

Figure 2. T-value of Latent Variable Path

Source : Lisrel Output

The hypothesis test was carried out by comparing the $t_{v a l u e}$ to the $t_{\text {table. The number of respondents }}$ is 221 , and the number of variables is three, then the value of $t_{\text {table }}$ is 1.97 . Hypothesis testing is based on structural equation modeling (SEM) analysis, where the level of significance of the path coefficient is obtained from the $t_{\text {value }}>1.97$ and standardized path coefficient $>0.05$. Table 4 below summarizes the results of path analysis.

Table 4 : The Results of Hypothesis Testing

\begin{tabular}{llllll}
\hline \hline No & Path & $\begin{array}{l}\text { Standardized } \\
\text { Coefficient }\end{array}$ & $\begin{array}{l}\mathbf{T}_{\text {coun }} \\
\mathbf{t}\end{array}$ & Significance & Result \\
\hline 1. & EC $\rightarrow$ WEE & 0.15 & 2.07 & Significant & Accepted \\
2. & EC $\rightarrow$ SE & 0.62 & 9.00 & Significant & Accepted \\
3. & SE $\rightarrow$ WEE & 0.49 & 5.73 & Significant & Accepted \\
4. & EC $\rightarrow$ SE $\rightarrow$ WEE & $0.30(0.62 * 0.49)$ & 5.00 & Significant & Accepted \\
\hline \hline
\end{tabular}

Based on Table 4, the results of hypothesis testing can be explained as follows:

Hypothesis $1\left(\mathrm{H}_{1}\right)$ is accepted. Therefore, Employee Competency (EC) is proven to be positively and significantly affect the Employee Work Engagement (WEE).

Hypothesis $2\left(\mathrm{H}_{2}\right)$ is accepted. Thus, it can be concluded that Employe Comptency (EC) has a positive and significant direct effect on Self Efficacy (SE)

Hypothesis $3\left(\mathrm{H}_{3}\right)$ is accepted. Thus, it can be concluded that Self Efficacy (SE) has a positive and significant direct impact on Employee Work Engagement (WEE)

Hypothesis $4\left(\mathrm{H}_{4}\right)$ is accepted. Employee Competency (EC) has a significant and positive direct effect on Employee Work Engagement (WEE). This means that Employee Competency (EC) has an indirect positive effect on Employee Work Engagement (WEE) through Self Efficacy (SE).

To find out the mediation role of Self Efficacy (SE) in the relationship between Employee Competency (EC) and Employee Work Engagement (WEE), the authors used the formula by Hayes (2018a) in which a . b = c - c'. The value of direct effect of Employee Competency (EC) on Self Efficacy (SE) is 0.62(a), and the value of direct effect of Self Efficacy (SE) on Employee Work Engagement (WEE) is 0.49 (b). Before controlled by Self Efficacy (SE), the value of direct effect of Employee Competency (EC) on Employee Work Engagement (WEE) is 0.15(c). The value of indirect effect of Employee Competency (EC) on Employee Work Engagement (WEE) through Self Efficacy (EC) is 0,30, which is obtained from the multiplication of the direct path of Employee Competency (EC) to Self Efficacy (SE) (0.62) with the direct path of Self Efficacy (SE) to Employee Work Engagement (WEE) (0.49). Therefore, the effect of Employee Competency (EC) on Employee Work Engagement after controlled by Self Efficacy (SE) is decreased to 0.30 (c'), which is obtained from 0.15 (c) -0.30 . As the decrease is not to zero. It can be concluded that Self Efficacy (SE) has partially mediated in the effect of Employee Competency 
(EC) on Employee Work Engagement (WEE). The illustration the direct and indirect effect of EC on WEE is shown in figure 3.
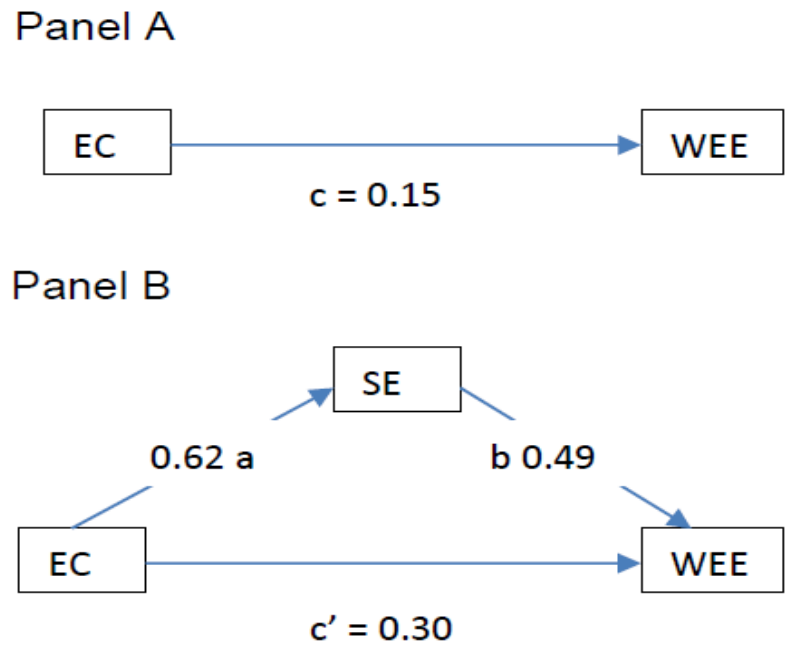

\section{Figure 3. Panel A : The Direct Effect of EC on WEE Panel B : The Indirect Effect of EC on WEE mediated by SE Source : (Hayes, 2018b)}

The summary of direct, indirect and total effect is shown in table 5

Table 5 : Direct Effect, Indirect Effect, and Total Effect

\begin{tabular}{cccccc}
\hline \hline From & Through & To & $\begin{array}{c}\text { Direct } \\
\text { Effect }\end{array}$ & Indirect Effect & $\begin{array}{c}\text { Total } \\
\text { Effect }\end{array}$ \\
\hline EC & - & WEE & 0.15 & - & 0.15 \\
EC & - & SE & 0.62 & - & 0.62 \\
SE & - & WEE & 0.49 & - & 0.49 \\
EC & SE & WEE & 0.49 & 0.30 & 0.79 \\
& & & & $(0.62 * 0.49)$ & \\
\hline
\end{tabular}

The combination of Employee Competency and Self Efficacy had a greater impact on Employee Work Engagement, with a combined effect regression coefficient of 0.79.

\section{DISCUSSION}

Employee Competency has a significant and positive direct effect on Employee Work Engagement. It can be interpreted that an increase in Employee Competency will lead to an increase in Employee Work Engagement. This findings reinforce the theory that employee competency means influencing followers to achieve a common objective (Mangkuprawira, 2009; Koscek, 2007). Through employee competency can be directed to the achievement of employee work engagement. The results of previous empirical studies (Malinda et al., 2018; Unnikrishnan, 2017) indicated that employee competency positively influenced the employee work engagement. It can be interpreted that the improvement of employee competency will affect the improvement of employee work engagement. Therefore, to enhance employee work engagement, employee competency must be improved. The improvement of employee competency should be done through the improvement of its indicators namely; intelektual, emotional and social. When those factors are strong, then employee competency can be stronger, which finally impact the higher employee work engagement. Based on the analysis, it is found that social competency has the highest score in shaping the employee competency. It means that social competency is the most representative indicator in explaining the latent variable of employee work engagement in Human Resoruce Development Agency (BPSDM) Ministry of Law and Human Rights Republic of Indonesia. BPSDM Ministry of Law and Human Rights Republic of Indonesia must keep maintaining the courage to take risks, because it is very important for the success of ministry.

Likewise, employee competency has a significant and positive direct effect on self efficacy. This relationship can be interpreted that if employee competency is applied better it will strengthen the self efficacy. Conversely, if employee competency is not good, it will have an impact on the weakening of self efficacy. This finding reinforce the theory that through competency, the appropriate self efficacy can be created and strengthened (Sedarmayanti, 2007). The results of this study is in line with the results of previous studies by (Lauermann, 2016) and (Shu, 2014) which found that employee competency has a direct positive and significant effect on self efficacy. 
Meanwhile, self efficacy has a significant and positive direct effect on employee work engagement. This means that to increase employee work engagement, Human Resource Development Agency (BPSDM) Ministry of Law and Human Rights Republic of Indonesia need to improve self efficacy. To strengthen self efficacy, Human Resource Development Agency (BPSDM) Ministry of Law and Human Rights Republic of Indonesia need to improve the 3 indicators which are shaping the self efficacy namely, level, generality and strenght. The improvement of each indicator will lead to an increase in employee work engagement. This finding has empirically proved and corroborated the result of previous studies in which self efficacy has positive effects on employee work engagement (Trilolita \& Ardi, 2017; Wen \& Driscoll, 2017; Fattah, 2017; Federici \& Skaalvik, 2011; Salanova et al., 2011; Ardi et al., 2017)

Based on the result, it is shown that generality gave the biggest contribution in shaping the self efficacy. It means that generality is the most representative indicator in explaining the latent variable of self efficacy in Human Resource Development Agency (BPSDM) Ministry of Law and Human Rights Republic of Indonesia. Human Resource Development Agency (BPSDM) Ministry of Law and Human Rights Republic of Indonesia must keep maintaining the generality because it This aspect can be assessed as good, if the individual can believe that his previous experience can help his current job, is able to handle different situations well, and makes the experience a path to success (Adianita et al., 2017). However, the strength was found to be the weakest indicator in explaining the self efficacy in Human Resource Development Agency (BPSDM) Ministry of Law and Human Rights Republic of Indonesia. Therefore, the main priority to improve self efficacy should be done by improving the strength. By understanding the strength of employees will direct their performance to achieve the goals of the organization. (Trilolita \& Ardi, 2017). The efforts to strengthen the self efficacy of generality Finally, self efficacy partially mediated the effect of employee competency on employee work engagement. An increase on employee competency indirectly caused an increase on employee work engagement through self efficacy. This means that to improve employee work engagement, the leaders need to improve the employee competency through self efficacy. When the self efficacy is increased, then it will ultimately improve the effect of employee competency on employee work engagement.

Various theories and empirical evidence through researches have shown a direct positive effect of employee competency on self efficacy and a direct positive effect of self efficacy on employee work engagement. Even though the study about the indirect effect of employee competency on employee work engagement through self efficacy has not been done, based on the logic of syllogism, it can be concluded that employee competency has a positive indirect effect on employee work engagement through self efficacy. This logic is supported by the results of this study which show that employee competency has a significant positive effect on employee work engagement through self efficacy. It can be interpreted that good employee competency will be able to increase employee work engagement, and through good self efficacy, the influence of employee competency in increasing employee work engagement will be stronger.

\section{CONCLUSION}

BPSDM Ministry of Law and Human Rights of the Republic of Indonesia should provide career development in organizations both individually and in organizations so that self-efficacy can be increased as an effort to achieve employee work engagement. Efforts to increase selfefficacy should be prioritized on increasing confidence in abilities and a positive outlook in interpreting levels (levels) to develop abilities through career development. So that employees will increase their work engagement.

It is better if the BPSDM Ministry of Law and Human Rights of the Republic of Indonesia provides opportunities for employees to develop job skills through career development that is relevant to the needs of the organization to anticipate and fulfill future work demands. Efforts to strengthen employee competency should be prioritized on social competency. Employees should really understand and understand the importance of employees in carrying out their duties to achieve common goals. To build a social competency, it is better if the BPSDM Ministry of Law and Human Rights of the Republic of Indonesia motivates employees to take opportunities or opportunities, so that employees can increase their self-efficacy so that it will increase the degree of employee work engagement.

Efforts to strengthen employee competencies should be prioritized on social competency. BPSDM Ministry of Law and Human Rights of the Republic of Indonesia must be able to provide an understanding of the vision, mission and objectives of the organization, besides helping employees who need assistance in their work so that employee self-efficacy increases and 
employee engagement also increases. In an effort to add to the repertoire of knowledge as well as in an effort to increase and also become input for further research which conducts research that is almost the same as related to human resource, it needs to be done intensively on other variables, especially those that theoretically and empirically can influence self-efficacy and employee work engagement

\section{REFERENCES}

Adianita, A. S., Mujanah, S., \& Candraningrat, C. (2017). Kompetensi Karyawan, Emotional Quotient Dan Self Efficacy Pengaruhnya Terhadap Organizational Citizenship Behavior Dan Kinerja Karyawan Pada Indomobil Grup Di Surabaya. Jurnal Riset Ekonomi Dan Manajemen, 17(1), 199. https://doi.org/10.17970/jrem.17.170114.id

Albrect, S. L. (2010). Employee Engagement: 10 Key Question for Reacearch and Practice" (N. : E. Elgar (ed.); p. h.3). New Horizon in Management.

Andrianto, A. H., \& Alsada, Y. (2019). The Conceptual Framework of Employee Engagement to Vigor, Dedication, and Absorption. International Journal of Social Relevance \& Concern, $7(1), 11-14$.

Ardi, V. T. P., Astuti, E. S., \& Sulistyo, C. W. (2017). Pengaruh Self-Efficacy terhadap Employee Engagement dan Kinerja Karyawan ( Studi pada Karyawan PT Telekomunikasi Indonesia Regional V Surabaya ). Jurnal Administrasi Bisnis, 52(1), 163-172.

Azoury, A., Daou, L., \& Sleiaty, F. (2013). Employee engagement in family and non-family firms. International Strategic Management, $1, \quad 11-29$. https://doi.org/http://dx.doi.org/10.1016/j/ism/2013.08.002

Bakker, A. B., \& Leiter, M. P. (2010). Work Engagement A Handbook of Essential Theory and Research. Psychology Press.

Bandura, A. (2009). Self - Efficacy in Changing Societies (A. Bandura (ed.); Transferre). Cambridge University Press.

Budiastuti, A. B. \& S. (2018). Pengaruh Self Efficacy, Employee Engagement, dan Servant Leadership Terhadap Organizational Citizenship Behavior Dalam Meningkatkan Kinerja. Jurnal Hummansi, 1(1), 39-52.

Darmawa, W., Brahmasari, I. A., \& Ratih, I. A. B. (2019). The Effect Of Transformational Leadership , Organizational Culture , Competence , And Self-Efficacy On Organizational Commitments, Ambidexterity Organizational And Performance Of Village Governments In East Nusa Tenggara Province. Archieces of Business Research, 7(3). https://doi.org/10.14738/abr.73.6339

Fattah, A. H. (2017). The Effect of Organizational Culture , Leader Behavior, Self-Efficacy, and Job Satisfaction on Job Performance of The Employees. Jurnal Terapan Manajemen Dan Bisnis, 3(2), 102-110.

Federici, R. A., \& Skaalvik, E. M. (2011). Principal self-efficacy and work engagement : assessing a Norwegian Principal Self-Efficacy Scale. Soc Psychol Educ, 123, 575-600. https://doi.org/10.1007/s11218-011-9160-4

Griffin, M. (2012). Organizational Behaviour Managing People and Organisations (Ru. Belanger (ed.); 10 edition). South Western Cengage Learning.

Hair, J. F., C. Black, W., Babin, B. J., \& Anderson, R. E. (2014). Multivariate Data Analysis (Seventh). Pearson Education Limited.

Hayes, A. F. (2018a). Introduction to Mediation, Moderation, and Conditional Process Analysis: A Regression-Based Approach. The Guilford Press.

Hayes, A. F. (2018b). Introduction to Mediation, Moderation, Conditional Process Analysis A Regression - Based Approach (Second Edi). The Guilford Press.

Heneman, Judge, M. (2015). Staffing Organizations (eighth Edi). Mc Graw - Hill.

Jr, J. F. H., Black, W. C., Babin, B. J., \& Anderson, R. E. (2014). Multivariate Data Analysis (Seventh Ed). Pearson New International Edition.

Kinicki, A., \& Fugata, M. (2016). Organizational Behavior L A Practical, Problem-Solving Approach. Mc Graw - Hill.

Koscek, M. I. (2007). Enerzing Organizations and New Method for Measuring Employee Engagement.

Lauermann, F. (2016). Teacher Professional Competence and Wellbeing : Understanding the Link Between General Pedagogical Knowledge, Self-Efficacy and Burnout. Learning and Instruction, 45, 9-19. https://doi.org/http://dx.doi.org/10.1016/j.learninstru.2016.06.006

Luthan, F. (2011). Organizational Behavior an Evidence - Based Approach (12th Editi). Mc Graw 
- Hill.

Macey, W. . (2009). Employee Ungagement: Tools for Analysis, Practice, and Competitive Advantage. Malden, MA;Wiley.

Maddux, J. E., \& Volkmann, J. (2010). Handbook of Personality and Self - Regulation (R. Hoyle (ed.)). Blackwell Publishing Ltd.

Malinda, S., Masyita, D., Nidar, S. R., \& Anwar, M. (2018). Agent's Competency to Work Engagement on Branchless Banking Implementation. Academy of Accounting and Financial Studies Journal, 22(6), 1-9.

Mangkuprawira. (2009a). Bisnis, Manajemen dan Sumberdaya Manusia (Cetakan ke). IPB Press.

Mangkuprawira, S. (2009b). Manajemen Sumber Daya Manusia. In Mycological Research (Vol. 2).

Marjoeki. (2016). Pedoman Penyelenggaraan Kementerian Hukum Dan Ham. Pengayoman.

Nikolov, R., Shoikova, E., Kovatcheva, E., \& Technologies, I. (2014). Competence Based Framework For Curriculum Development. Sofia. https://doi.org/10.13140/RG.2.1.4201.6086

Osei, A. J., \& Ackah, O. (2015). Employee' S Competency and Organizational Performance in the Pharmaceutical Industry. International Journal of Economics, Commerce and Managment, $\operatorname{III}(3), 1-9$.

Salanova, M., Lorente, L., J, M., Chambel, \& Martinez, I. M. (2011). Linking Transformational Leadership to Nurses' Extra-Role Performance: The Mediating Role of Self-Efficacy and Work Engagement. Journal of Advanced Nursing, 67(10), 2256-2266. https://doi.org/10.1111/j.1365-2648.2011.05652.x

Schaufeli, \& Bakker, W. (2013). What is Engagement "Employee Engagement in Theory and Practice. Routledge.

Schaufeli, W. B., Salanova, M., Bakker, A. B., \& Alez-rom, V. G. (2002). The Measurement of Engagement and Burnout : a Two Sample Confirmatory Factor Analytic Aproach. Jornal of Happiness Studies, 3, 71-92.

Sedarmayanti. (2007). Manajemen Sumber Daya Manusia; Reformasi Birokrasi dan Manajemen Pegawai Negeri Sipil (D. Sumayyah (ed.); Edisi Revi). Refika Aditama.

Sedarmayanti. (2017). Perencanaan dan Pengembangan Sumber Daya Manusia "Untuk Meningkatkan Kompetensi, Kinerja, dan Produktivitas Kerja (Cetakan ke). Refika Aditama.

Shu, L.-L. (2014). The Effects of Scenario-Based Simulation Course Training on Nurses' Communication Competence and Self-Efficacy. Journal of Professional Nursing. https://doi.org/10.1016/j.profnurs.2014.05.007

Suwandana, I. G. M. (2016). Pengaruh Self Efficacy terhadap Keterlibatan Kerja dan Kepuasan Kerja Karyawan pada IBIS Styles Bali Benoa Hotel. E-Jurnal Manajemen Unud, 5(5), 31913218.

Trilolita, V., \& Ardi, P. (2017). Pengaruh Self Efficacy Terhadap Employee Engagement Dan Kinerja Karyawan ( Studi pada Karyawan PT Telekomunikasi Indonesia Regional V Surabaya ). Jurnal Administrasi Bisnis (JAB), 52(1).

Truss, K., Soane, E., Delbridge, R., Alfes, K., Shantz, A., \& Petrov, G. (2013). Employee Enagement, Organisational Performance and Individual Well-being: Exploring $\mathrm{THe}$ Evidence, Developing The Theory. The International Journal of Human Resource Management. https://doi.org/10.1080/09585192.2011.552282

Unnikrishnan, S. (2017). The Effect of Managerial Competencies on Employee Engagement in Multinational IT Industries. International Journal of Latest Trends in Engineering and Technology, 7(3), 28-34. https://doi.org/http://dx.doi.org/10.21172/1.73.504

Wen, X., \& Driscoll, O. (2017). Self-efficacy and Work Engagement : test of a chain model Author Griffith Research Online. International Journal of Manpower.

Wirotama, S. (2017). Employee Engagement dalam Teori Maslow.

Yakın, M., \& Erdil, O. (2012). Relationships Between Self-Efficacy and Work Engagement and the Effects on Job Satisfaction: A Survey on Certified Public Accountants. Procedia - Social and Behavioral Sciences, 58, 370-378. https://doi.org/10.1016/j.sbspro.2012.09.1013 